\title{
Seroprevalence of Kaposi's sarcoma- associated herpesvirus in various populations in Cuba
}

\author{
Vivian Kourí, ${ }^{1}$ Sybil M. Eng, ${ }^{2}$ María E. Rodríguez, ${ }^{3}$ Sonia Resik, ${ }^{1}$ \\ Odalys Orraca, ${ }^{4}$ Patrick S. Moore, ${ }^{2}$ and Yuan Chang ${ }^{2}$
}

Suggested citation Kourí V, Eng SM, Rodríguez ME, Resik S, Orraca O, Moore PS, Chang Y. Seroprevalence of Kaposi's sarcoma-associated herpesvirus in various populations in Cuba. Rev Panam Salud Publica. 2004; 15(5):320-5.

ABSTRACT Objective. Little is known about the prevalence and distribution of Kaposi's sarcoma-associated herpesvirus (KSHV) infection in the Caribbean. The aim of this study was to determine rates of KSHV seropositivity in various populations in Cuba.

Methods. During the years 1998 to 2002 we screened serum samples from 410 subjects in Cuba. Serologic screening for KSHV antibodies was a two-step process using (1) indirect immunofluorescence assay (IFA) specifically reactive to the KSHV latency-associated nuclear antigen (LANA) encoded by open reading frame 73 (ORF73), and (2) confirmatory immunoblot using recombinant KSHV ORF65.2, a lytically expressed, 20-kilodalton protein as the target antigen. Five different populations were studied: (1) 45 AIDS patients with Kaposi's sarcoma (AIDS-KS), (2) 154 HIV-1-infected patients without clinical evidence of KS, (3) 171 $H I V$-negative blood donors, (4) 27 consecutive kidney transplant recipients, who were HIVnegative, and (5) 13 contacts (sexual contacts or relatives) of the AIDS-KS-affected patients. Results. Among the 45 AIDS-KS subjects, 35 of them (77.8\%) were KSHV-seropositive. Thirty-two of the $154 \mathrm{HIV}$-positive patients without KS (20.8\% of them) were KSHV-seropositive, and 6 of the 13 contacts of KS-affected patients (46.2\% of them) were infected with KSHV. In contrast to other researchers, we did not find in the populations that we studied in Cuba that KSHV seropositivity was associated with male homosexual or bisexual activity. We found high KSHV seropositivity rates among women reporting sexual contact with bisexual men and among men who had acquired an HIV infection in Africa. There were low rates of KSHV infection among the blood donors $(1.2 \%)$ and the renal transplant recipients $(0.0 \%)$. The low rates of KSHV infection that we found among the non-HIV-infected populations in Cuba are similar to patterns found in populations in Europe and in the United States.

Conclusions. Together with similar results from Brazil, Jamaica, and the United States of America, our results suggest that KSHV infection is uncommon in some populations in the Western Hemisphere and that KSHV is largely confined to patients with AIDS-associated KS.

Key words Herpesvirus 8, human; sarcoma, Kaposi; HIV; acquired immunodeficiency syndrome; risk factors; seroepidemiologic studies; Cuba.

Pedro Kourí Institute of Tropical Medicine, Virology Department, Havana, Cuba. Send correspondence to: Vivian Kourí, Pedro Kourí Institute of Tropical Medicine, Virology Department, Autopista Novia del Mediodía, Km 6, La Lisa, P.O. Box
601, Marianao 13, Havana, Cuba; e-mail: vkouri@ ipk.sld.cu; fax: 5372046051.

2 Hillman Cancer Center, Pittsburgh, Pennsylvania, United States of America.
Pedro Kourí Institute of Tropical Medicine, Dermatology Department, Havana, Cuba.

4 Blood Bank of Pinar del Río, Pinar del Río, Pinar del Río, Cuba. 
Kaposi's sarcoma (KS) was first described by Moritz Kaposi in 1872 (1), and there is ample evidence to suggest that Kaposi's sarcoma-associated herpesvirus (KSHV), a newly discovered herpesvirus also known as human herpesvirus 8 (HHV8), plays an etiologic role in KS (2). Prior to the introduction of highly active antiretroviral therapy (HAART), KS was the most frequent neoplasm associated with human immunodeficiency virus type 1 (HIV-1) infection, occurring in approximately $30 \%$ of HIV-1-infected homosexual men (3). In the general populations of North America and Northern Europe, $\mathrm{KSHV}$ infection is uncommon $(<5 \%)$ and is spread principally through sexual transmission, particularly among gay and bisexual men (4). In Mediterranean and African countries, there are, respectively, intermediate infection rates $(5 \%-20 \%)$ and high infection rates $(>30 \%)$, and the virus appears to be spread through both sexual modes of transmission and as-yet-undefined nonsexual modes of transmission (5).

Serologic tests for KSHV include an indirect immunofluorescence assay (IFA) on KSHV-infected cells, targeted to the latency-associated nuclear antigen (LANA) encoded by KSHV open reading frame 73 (ORF73) $(6,7)$. This assay appears to be highly specific for KSHV infection (100\%) and typically displays $80 \%$ sensitivity among KS patients with AIDS. The sensitivity of the LANA IFA may approach $100 \%$ in KS patients without HIV (unpublished observation, Patrick S. Moore, 1996). An immunoblot technique (Western blot) using recombinant KSHV ORF65.2, a lytically expressed, 20-kilodalton recombinant protein, as the antigen has also been developed and characterized and shows approximately the same sensitivity as the LANA IFA (8).

In Cuba there are now more than 4500 people living with HIV. Fiftyeight of these individuals have developed KS. Although KS is not common among the general population of Cuba, the past five years have seen an increase in AIDS-associated KS (AIDS$\mathrm{KS}$ ) rates among HIV-infected persons in the country (unpublished observation, María E. Rodríguez, 2000). From the beginning of the HIV epidemic until 1997 Cuba had only 21 KS cases. However, in the 1998-2001 period 37 new cases were diagnosed. Given this increase in cases, we decided to examine rates of KSHV infection in various populations in Cuba.

\section{MATERIALS AND METHODS}

\section{Serum archive}

Sera from all HIV-positive individuals in Cuba are stored in the serum archive of the Sexually Transmitted Diseases Laboratory at the Pedro Kourí Institute of Tropical Medicine in Havana, Cuba. Following seroconversion to HIV positivity, samples are collected and banked from each subject every two to three years to test for antibodies against cytomegalovirus, Epstein-Barr virus, and herpes simplex virus. $\mathrm{Nu}$ merous serum samples, each one taken at a different time point, are thus available for each HIV-positive individual.

\section{Populations and sampling}

Serum samples were collected by one of the authors (VK) from a total of 410 subjects from five population groups that, according to previous reports $(6,7)$, were presumed to be at either high risk or low risk for KSHV infection.

The first two of the five groups were AIDS patients with KS and HIV-1/ AIDS patients without KS. Both of these groups were presumed to be of high risk. Sera for both groups were selected from the Sexually Transmitted Diseases serum archive at the Pedro Kourí Institute of Tropical Medicine.

The first group consisted of 45 known AIDS-KS patients, who had been diagnosed in the period from 1991 to 2002. The KS diagnoses had been clinically and histologically confirmed according to standard criteria (9), and 8 cases were diagnosed at autopsy. All the sera from the AIDS-KS patients selected for KSHV testing were dated either after confirmation of KS, for those diagnosed while still living, or imme- diately prior to death, for those who were diagnosed as KS postmortem.

The second group consisted of 154 patients who were infected with HIV-1 or were in the AIDS stage (HIV-1/ AIDS) and who had no clinical evidence of KS. Of the 154, 35 of them were considered AIDS cases at the time that the study was performed, based on the 1983 classification criteria of the Centers for Disease Control and Prevention of the United States. As facilities in Cuba were not able to determine CD4 counts for these subjects at the times of their AIDS diagnosis, these data were unavailable for clinical staging purposes. Sera from these 154 HIV-1/AIDS patients without KS were randomly selected from the serum archive, as multiple samples were available for each subject. The selection was made by means of a table of random numbers.

Risk factor data and basic demographic data on the 45 AIDS-KS patients and on the $154 \mathrm{HIV}$-seropositive persons without KS were available through the HIV registry maintained by the Santiago de las Vegas sanatorium. Serological reactivity to HIV-1 had been previously determined by enzyme immunoassay (DAVIH, Havana, Cuba), and positive results were confirmed by Western blot tests (Organon Teknika, Turnhout, Belgium).

The third of the five groups consisted of $171 \mathrm{HIV}$-negative blood donors from the Central Blood Bank of the city of Pinar del Río who were also negative for hepatitis B surface antigen, hepatitis $\mathrm{C}$ antibodies, and venereal disease research laboratory antibodies. The blood donors were considered at low risk. The fourth group was comprised of 27 consecutive kidney transplant recipients, who were HIV-negative; they were also presumed to be at low risk.

The fifth group consisted of 13 contacts of AIDS-KS-affected patients. All 13 contacts agreed to be tested. Of the 13 contacts, 11 of them were HIVseropositive sexual partners of AIDSKS patients, and the other 2 were HIVseronegative relatives (mothers) of AIDS-KS patients. The persons in this group, especially the sexual contacts, were considered to be at high risk for KSHV infection. 


\section{Serologic testing}

Serum samples were coded, and KSHV serostatus was determined in a double-blinded manner. All sera had been stored at $-20{ }^{\circ} \mathrm{C}$, except for some of the very old sera from KS patients, which might have been frozen and thawed at least twice. To decrease potential viral biohazards, all serum samples were heated to $56{ }^{\circ} \mathrm{C}$ for 30 minutes before use. Antibodies to the latency-associated nuclear antigen (LANA) were determined by indirect immunofluorescence assay (IFA) on an Epstein-Barr virus-negative, primary effusion lymphoma cell line (BCP-1) latently infected with KSHV, using the protocol previously reported by Gao S et al. (6) and by Martin J et al. (4).

Samples were scored IFA-positive if the punctate nuclear staining pattern specific for KSHV-related antigens was observed. Confirmatory Western blotting using the lytically expressed KSHV ORF65.2 was performed, and the samples were considered positive when a band appeared to the expected size (8). The IFA and the immunoblot were each performed twice for every sample, with discordant results assayed a third time to resolve discrepancies. As serologic assays for KSHV are still in their infancy and conservative seroprevalence estimates were the goal, only sera scoring positive by both IFA and immunoblot were considered positive for KSHV. Positive and negative controls were selected from samples previously tested with both systems (IFA and Western blot).

This research was performed from August 1998 to January 2002, in a collaboration between Columbia University, in New York City, New York, United States of America, and the Pedro Kourí Institute of Tropical Medicine, in the city of Havana, Cuba.

\section{Statistical analyses}

Descriptive statistics (percentages) were used. Comparisons of frequencies were carried out using the chisquare test, and Fisher's exact test was used to examine differences in proportions. All $P$ values were two-sided.

\section{Ethics aspects}

The procedures followed were in accordance with the ethical standards of the responsible committee on human experimentation of the Cuban Ministry of Health and with the Hel- sinki Declaration of 1975. Appropriate informed consent was obtained from the patients, and the guidelines for human experimentation of the Department of Health and Human Services of the United States and/or each authors' institution were followed in the conduct of the clinical research.

\section{RESULTS}

A basic demographic profile of the five populations in our study is given in Table 1 . The 45 patients with AIDSKS ranged in age from 17 to 58 years (median, 33.4 years); $32(71.1 \%)$ were white, $7(15.6 \%)$ were black, and 6 (13.3\%) were mestizo (data not shown). A homosexuality/bisexuality risk factor was found in 32 of the 36 male AIDS-KS patients (88.9\% of them); the other 4 men were heterosexual. The 9 women among the 45 AIDSKS patients (20\% of them) comprised a substantial portion of that group. Three of the 4 male heterosexual AIDS-KS patients acquired HIV infection in Africa, while all 9 female AIDSKS patients had had multiple contacts with homosexual/bisexual men (data not shown).

The HIV-seropositive group without $\mathrm{KS}$ ranged in age from 16 to 70

TABLE 1. Demographic profile of the five cohorts in Cuba that were examined for antibodies to Kaposi's sarcoma-associated herpesvirus, 1998-2002

\begin{tabular}{|c|c|c|c|c|c|c|c|c|c|c|}
\hline \multirow{2}{*}{$\begin{array}{l}\text { Demographic } \\
\text { characteristic }\end{array}$} & \multicolumn{2}{|c|}{$\begin{array}{l}\text { AIDS patients } \\
\text { with Kaposi's } \\
\text { sarcoma (KS) } \\
\quad(n=45)\end{array}$} & \multicolumn{2}{|c|}{$\begin{array}{l}\text { HIV/AIDS } \\
\text { patients without } \\
\text { KS } \\
(n=154)\end{array}$} & \multicolumn{2}{|c|}{$\begin{array}{c}\text { Blood } \\
\text { donors } \\
(n=171)\end{array}$} & \multicolumn{2}{|c|}{$\begin{array}{l}\text { Kidney } \\
\text { transplant } \\
\text { recipients } \\
(n=27)\end{array}$} & \multicolumn{2}{|c|}{$\begin{array}{l}\text { Contacts of } \\
\text { KS patients } \\
\quad(n=13)\end{array}$} \\
\hline & No. & $\%$ & No. & $\%$ & No. & $\%$ & No. & $\%$ & No. & $\%$ \\
\hline \multicolumn{11}{|l|}{ Age (yr) } \\
\hline $15-24$ & 8 & $17.8 \%$ & 71 & $46.1 \%$ & 9 & $5.3 \%$ & 21 & $77.8 \%$ & 2 & $15.4 \%$ \\
\hline $25-30$ & 12 & $26.7 \%$ & 41 & $26.6 \%$ & 33 & $19.3 \%$ & 4 & $14.8 \%$ & 7 & $53.8 \%$ \\
\hline$>30$ & 25 & $55.6 \%$ & 42 & $27.3 \%$ & 129 & $75.4 \%$ & 2 & $7.4 \%$ & 4 & $30.8 \%$ \\
\hline \multicolumn{11}{|l|}{ Sex } \\
\hline Female & 9 & $20.0 \%$ & 34 & $22.1 \%$ & 35 & $20.5 \%$ & 8 & $29.6 \%$ & 5 & $38.5 \%$ \\
\hline Male & 36 & $80.0 \%$ & 120 & $77.9 \%$ & 136 & $79.5 \%$ & 19 & $70.4 \%$ & 8 & $61.5 \%$ \\
\hline \multicolumn{11}{|l|}{ Sexual behavior } \\
\hline Male bisexual or homosexual & 32 & $71.1 \%$ & 104 & $67.5 \%$ & $N A^{a}$ & NA & NA & NA & 8 & $61.5 \%$ \\
\hline Male heterosexual & 4 & $8.9 \%$ & 16 & $10.4 \%$ & NA & NA & NA & NA & 0 & $0.0 \%$ \\
\hline Female heterosexual & 9 & $20.0 \%$ & 34 & $22.1 \%$ & NA & NA & NA & NA & 5 & $38.5 \%$ \\
\hline
\end{tabular}


years (median age, 38.3); 119 of the 154 $(77.3 \%)$ were white, $14(9.1 \%)$ were black, and $21(13.7 \%)$ were mestizo. The sexual behavior of this group was similar to that reported for the AIDSKS patients.

The contacts group consisted of 8 homosexual/bisexual males who were sexual partners of KS-affected patients, and 5 women. Of these 5 women, 3 of them were sexual partners of AIDS patients with KS, and the other 2 were mothers of KS-affected patients. The 11 sexual partners were all HIVseropositive.

\section{Antibody seroreactivity to Kaposi's sarcoma-associated herpesvirus among the five cohorts in Cuba}

Among the 45 AIDS-KS patients, 37 of them $(82.2 \%)$ were IFA-positive for LANA seroreactivity; 35 of these 37 LANA-positive AIDS-KS patients were confirmed positive by the ORF65.2 immunoblot (Table 2).

Of the 154 HIV-positive persons without KS, 34 of them (22.1\%) were also KSHV-seropositive by the IFA, and 32 of the 34 were confirmed by immunoblot (Table 2).

TABLE 2. Results of testing for antibodies to Kaposi's sarcoma-associated herpesvirus (KSHV) in 410 Cuban serum samples from five cohorts, 1998-2002

\begin{tabular}{|c|c|c|c|c|c|}
\hline \multirow[b]{2}{*}{ Study cohort } & \multirow{2}{*}{$\begin{array}{c}\text { No. of } \\
\text { subjects tested }\end{array}$} & \multicolumn{2}{|c|}{$\begin{array}{c}\text { Positive } \\
\text { LANA IFA }\end{array}$} & \multicolumn{2}{|c|}{$\begin{array}{c}\text { Positive } \\
\text { ORF65.2 IB }\end{array}$} \\
\hline & & No. & $\%$ & No. & $\%$ \\
\hline AIDS patients with $\mathrm{KS}$ & 45 & 37 & $82.2^{c}$ & 35 & $77.8^{\mathrm{c}}$ \\
\hline HIV/AIDS patients without KS & 154 & 34 & $22.1^{c}$ & 32 & $20.8^{c}$ \\
\hline Blood donors & 171 & 2 & 1.2 & 2 & 1.2 \\
\hline Kidney transplant recipients & 27 & 0 & 0.0 & 0 & 0.0 \\
\hline Contacts of KS-affected patients & 13 & 6 & 46.2 & 6 & 46.2 \\
\hline
\end{tabular}

a LANA IFA = latency-associated nuclear antigen immunofluorescence assay.

${ }^{b}$ ORF65.2 IB = open reading frame 65.2 immunoblot.

c $P<0.0001$, from Fisher's exact test after pairwise comparison of the indicated group to the blood donor group.

Of the 171 blood donors (all of whom were HIV-negative), only 2 of them $(1.2 \%)$ were positive for KSHV infection; none of the 27 kidney transplant recipients was infected (Table 2). These results are consistent with these two groups' presumed low risk for KSHV infection.

In the contacts group we found positive results to KSHV antibodies in 6 of the 13 persons ( $46.2 \%$ of them) assayed by both methods (Table 2 ). The two mothers of the KS-affected patients were seronegative for KSHV.
Subgroup analyses of KSHV seropositivity among HIV-positive subjects with and without KS

As shown in Table 3, both men and women had relatively high KSHV seroprevalence rates. Of the $164 \mathrm{HIV}$ 1-positive men, 59 of them $(36.0 \%)$ were found seroprevalent for KSHV. Of the 46 HIV-1-positive women, 14 of them $(30.4 \%)$ were found seroprevalent for KSHV. Subjects with HIV and KSHV coinfection were significantly older than their counterparts without

TABLE 3. Subgroup analysis of Kaposi's sarcoma-associated herpesvirus (KSHV) seroreactivity among HIV-positive Cuban subjects with or without Kaposi's sarcoma (KS), 1998-2002

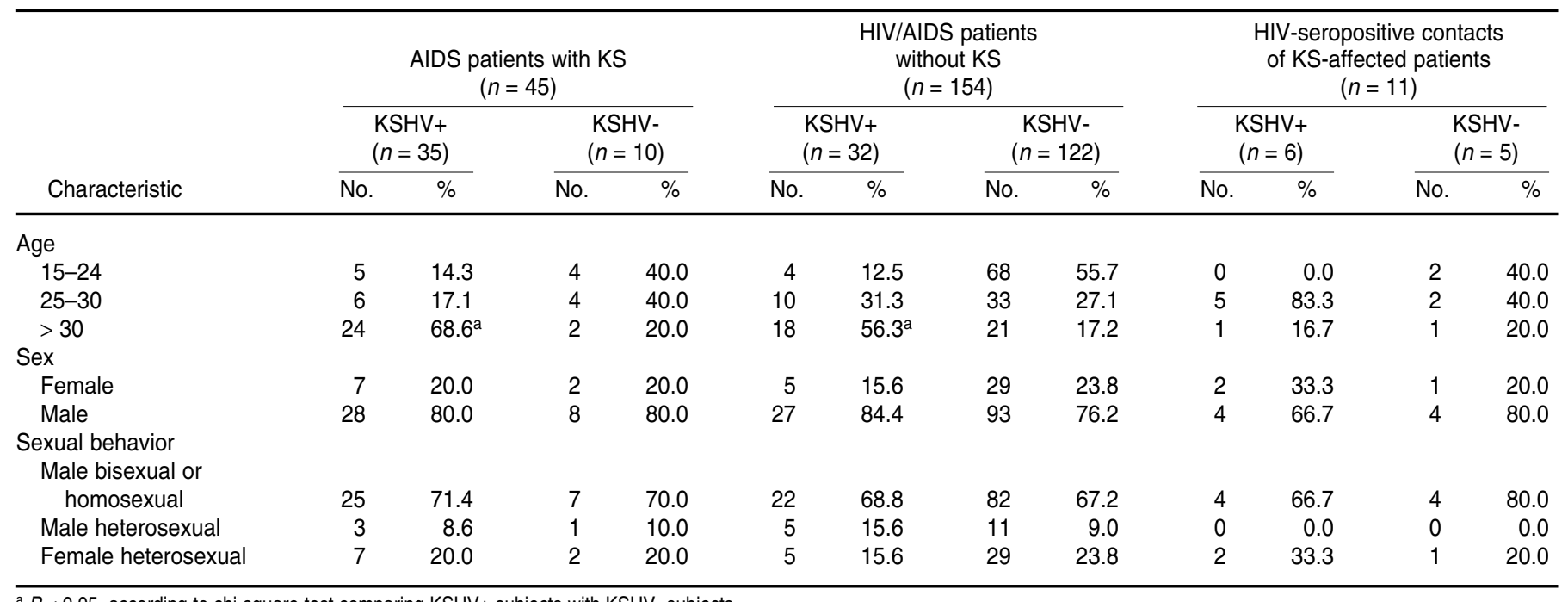

a $P<0.05$, according to chi-square test comparing KSHV+ subjects with KSHV- subjects. 
KSHV infection $(P<0.05)$; this was true for both the persons with KS and the persons without KS.

The majority of HIV-positive persons studied were homosexual or bisexual men. Homosexuality/bisexuality was not significantly associated with KSHV infection among either subjects with KS or subjects without KS. Among the group of patients with $\mathrm{KS}$, the proportion of homosexual or bisexual males who were KSHVseropositive was $78.1 \%$ ( 25 of 32), compared to $75.0 \%$ ( 3 of 4 ) for heterosexual men $(P=0.99)$. In contrast, among the group of HIV-seropositive patients who did not have KS, the proportion of bisexual or homosexual males who were seropositives for KSHV was $21.1 \%$ (22 of 104), compared to $31.3 \%$ (5 of 16) for heterosexual men $(P=0.36)$. For the sexual contacts the proportion of homosexual or bisexual males infected with KSHV was 50\% (4 of 8).

\section{DISCUSSION}

The studies performed by Whitby and colleagues (10) and by Smith and colleagues (11) found homosexuality to be strongly associated with AIDS-KS. In contrast, in our study in Cuban populations we found that heterosexual men and heterosexual women comprised a substantial portion of the AIDS-KS patients (8.9\% and $20.0 \%$, respectively). Various factors could have contributed to this finding in Cuba, including the high number of sexual partners and the types of sexual practices of these heterosexual men and women. Four of the men in our study acquired HIV infection in Africa through heterosexual contact, and they might have also been infected with HHV8 at the same time. All nine female AIDS-KS patients had had multiple contacts with homosexual or bisexual men. In both the HIV-positive persons with KS and those without KS, there was a predominance of whites, which is also true for the HIV-positive population overall in Cuba.

The $82.2 \%$ positivity found by using IFA in the group of AIDS patients with $\mathrm{KS}$ is consistent with previous reports regarding using IFA to assess LANA seroreactivity $(4,6,7)$. As expected, the two-step IFA/immunoblot (Western blot) protocol resulted in a relatively low test sensitivity but provided a conservative estimate of KSHV seropositivity as well as a relatively high test specificity. Negative cases could be due to several reasons. One reason is the sensitivity of the tests, which is about an $80 \%$ for IFA, and lower for the Western blot. Another possible reason is the history of freezing and thawing of some of the older serum samples. Finally, since the HIV-infected patients with KS are in the AIDS stage, the antibodies response may be affected, resulting in a false-negative response to HHV8, in the same way that occurs for HIV antibodies.

The rates of KSHV prevalence that we found in the various populations in Cuba suggest a pattern of KSHV infection that is similar to that for populations in Japan, Northern Europe, and the United States (10-12) and different from that of populations in Italy and Uganda, two countries where this virus is widespread $(13,14)$. Our results in Cuba were also similar to those that Keller et al. (15) reported for Brazil. Those researchers reported a KSHV prevalence level of $79.5 \%$ among HIV-positive patients with KS and a level of $18.5 \%$ among HIV-positive patients without KS.

In Cuba both the HIV-positive men and the HIV-positive women (including both those with and without KS) as well as the sexual contacts of the KSaffected patients had relatively high KSHV seroprevalence rates. That finding is similar to what has been reported for sexually active HIV-positive populations in Europe (11). Most researchers consider homosexuality to be a risk factor for KSHV infection and that this risk factor is mainly related to the persistence of unprotected orogenital sex in this group. This obviously does not represent the usual route of transmission of HHV8 in endemic countries, where most of the transmission appears to occur in childhood (16).

In the case of Cuba, homosexual or bisexual behavior was not significantly associated with KSHV infection among subjects with KS or subjects without KS.
This could be due to the fact that KS was very rare in Cuba before the AIDS era, even in transplant patients. The first Cuban HIV cases were persons who had become infected heterosexually while they were in Africa. These persons may also have become infected with KSHV while they were there, given that Cuba's first AIDS-KS patients had been in Africa. However, since the numbers of heterosexual males in our study were low compared with the numbers of homosexual/bisexual males, we suggest that this conclusion should be interpreted cautiously.

Further studies of KSHV transmission in Cuba should be carried out to clarify these issues. Our results are important for Cuban health authorities and draw attention to a new virus that is increasing in Cuba's HIV-infected population. This virus may also spread to persons who are not HIV-infected, thus representing a threat to the country.

Our analyses are consistent with previous observations of a strong association between KSHV seropositivity and KS among AIDS patients. Our analyses also suggest that KSHV transmission patterns in Cuba resemble those seen in Northern Europe and the United States. However, we didn't select a random sample of persons from the Cuban general population, but only from blood donors who were negative for hepatitis B surface antigen, hepatitis $C$, and venereal disease research laboratory antibodies. Therefore, we did not reach definitive conclusions regarding the circulation of KSHV in the non-HIV-infected Cuban population, including blood donors and kidney transplant recipients. Together with similar results from Brazil (15), Jamaica (17), and the United States (6), our study indicates that KSHV infection is uncommon in some populations in the Western Hemisphere and that KSHV is largely confined to patients with AIDS-associated KS.

Acknowledgments. Research done at the laboratory of Patrick Moore was funded through grant \#CA-73564 from the National Cancer Institute of the United States. Other funding for our study came from the Pedro Kourí Institute of Tropical Medicine. 


\section{REFERENCES}

1. Kaposi M. Idiopathic multiple lesions of the skin. Arch Dermatol Syphil. 1872;4:265-73.

2. Chang Y, Cesarman E, Pessin M, Lee F, Culpepper J, Knowles D, Moore P. Identification of herpesvirus-like DNA sequences in AIDS-associated Kaposi's sarcoma. Science. 1994;265:1865-9.

3. Sarid R, Olsen SJ, Moore P. Kaposi's sarcomaassociated herpesvirus: epidemiology, virology, and molecular biology. Adv Virus Res. 1999;52:139-232.

4. Martin J, Ganem D, Osmond D, Page-Shafer K, Macrae D, Kedes D. Sexual transmission and the natural history of human herpesvirus 8 infection. New Engl J Med. 1998;338:948-54.

5. Wilkinson D, Sheldon J, Gilks C, Schulz T. Prevalence of infection with human herpesvirus 8/Kaposi's sarcoma-associated herpesvirus in rural South Africa. S Afr Med J. 1999; 89:554-7.

6. Gao S, Kingsley L, Li M, Zheng W, Parravicini $\mathrm{C}$, Ziegler J, et al. KSHV antibodies among Americans, Italians, and Ugandans with and without Kaposi's sarcoma. Nature Med. 1996; 2:925-8.

7. Kedes D, Operskalski E, Busch M, Kohn R, Flood J, Ganem D. The seroepidemiology of human herpesvirus 8 (Kaposi's sarcomaassociated herpesvirus): distribution of infection in KS risk groups and evidence for sexual transmission. Nature Med. 1996;2:918-24.
8. Simpson G, Schulz T, Whitby D, Cook P, Boshoff C, Rainbow L, et al. Prevalence of Kaposi's sarcoma-associated herpesvirus infection measured by antibodies to recombinant capsid protein and latent immunofluorescence antigen. Lancet. 1996;348:1133-8.

9. Titus JL, Kim H. Blood vessels and lymphatics. In: Kissane JM, ed. Anderson's pathology. 9th ed. Vol. I. St. Louis: C.V. Mosby Company; 1990. Pp. 752-70.

10. Whitby D, Smith N, Matthews S, O'Shea S, Sabin C, Kulasegaram R, et al. Human herpesvirus 8: seroepidemiology among women and detection in the genital tract of seropositive women. J Infect Dis. 1999;179:234-6.

11. Smith N, Sabin C, Gopal R, Bourboulia D, Labbet W, Boshoff C, et al. Serologic evidence of human herpesvirus 8 transmission by homosexual but not heterosexual sex. J Infect Dis. 1999;180:600-6.

12. Katano $H$, Iwasaki $T$, Baba N, Terai M, Mori $\mathrm{S}$, Iwamoto $\mathrm{A}$, et al. Identification of antigenic proteins encoded by human herpesvirus 8 and seroprevalence in the general population and among patients with and without Kaposi's sarcoma. J Virol. 2000;74: 3478-85.

13. Perna AM, Bonura F, Vitale F, Viviano E, Di Benedetto MA, Ajello F, et al. Antibodies to human herpes virus type 8 (HHV8) in general population and in individuals at risk for sexu- ally transmitted diseases in Western Sicily. Int J Epidem. 2000;29:175-9.

14. Ziegler J, Newton R, Bourboulia D, Casabonne D, Beral V, Mbidde E, et al. Risk factors for Kaposi's sarcoma: a case-control study of HIV-seronegative people in Uganda. Int J Cancer. 2003;103:233-40.

15. Keller R, Zago A, Viana MC, Bourboulia D, Desgranges C, Casseb J, et al. HHV-8 infection in patients with AIDS-related Kaposi's sarcoma in Brazil. Braz J Med Biol Res. 2001;34: 879-86.

16. Goudsmit J, Renwick N, Dukers N, Coutinho R, Heisterkamp S, Bakker M, et al. Human herpesvirus 8 infections in the Amsterdam Cohort Studies (1984-1997): analysis of seroconversions to ORF65 and ORF73. Proc Natl Acad Sci U S A. 2000;97:4838-43.

17. Manns A, Strickler H, Hanchard B, Manassaram D, Waters D, Ablashi D. Age- and sexspecific seroprevalence of human herpesvirus 8 in Jamaica. J Natl Cancer Inst. 1998;90:1102-4.

Manuscript received 20 June 2003. Revised version accepted for publication 30 January 2004
RESUMEN

\section{Seroprevalencia} del herpesvirus asociado con el sarcoma de Kaposi en diversas poblaciones en Cuba
Objetivo. Se sabe poco acerca de la prevalencia y distribución en el Caribe de la infección por el herpesvirus asociado con el sarcoma de Kaposi (HVSK). El objetivo del presente estudio fue determinar las tasas de seropositividad a HVSK en diversas poblaciones en Cuba.

Métodos. Durante el período de 1998 a 2002 se examinaron muestras de suero de 410 personas en Cuba. El tamizaje serológico de los anticuerpos contra HVSK se realizó en dos pasos con las siguientes técnicas: 1) ensayo de inmunofluorescencia indirecta (IFI) con reactividad específica a la porción del antígeno de HVSK asociado a la latencia (ANAL) que está codificada por la plantilla de lectura abierta 73 (ORF73), y 2) inmunoblot (Western) confirmatorio, usando como antígeno blanco la proteína ORF65.2 de HVSK recombinante, que tiene 20 kilodaltones y se expresa durante la infección lítica. Cinco poblaciones diferentes fueron estudiadas: 1) 45 pacientes de sida con sarcoma de Kaposi (sida-KS); 2) 154 pacientes infectados por VIH-1 pero sin signos clínicos de sarcoma de Kaposi (SK); 3) 171 donantes de sangre con seronegatividad a VIH; 4) 27 receptores consecutivos de transplantes renales con seronegatividad a VIH y 5) 13 contactos (sexuales o por parentesco) de los pacientes de sida con SK.

Resultados. De las 45 personas con sida y SK, $35(77,8 \%)$ mostraron seropositividad a HVSK. Treinta y dos $(20,8 \%)$ de los 154 pacientes con seropositividad a VIH pero sin SK mostraron seropositividad a HVSK, y 6 de los 13 contactos $(46,2 \%)$ de pacientes con SK estaban infectados por HVSK. A diferencia de otros investigadores, los autores del presente estudio no encontraron ninguna asociación entre la seropositividad a HVSK y la actividad homosexual o bisexual en personas de sexo masculino en las poblaciones cubanas estudiadas. En cambio, sí hallaron tasas elevadas de seropositividad a HVSK en mujeres que declararon haber tenido contacto sexual con hombres bisexuales y en hombres que habían adquirido la infección por VIH en el África. Las tasas de infección por HVSK fueron bajas en los donantes de sangre $(1,2 \%)$ y en los receptores de transplantes renales $(0,0 \%)$. Las tasas de infección por HVSK halladas en las poblaciones cubanas sin infección por VIH fueron tan bajas como las observadas en Europa y Estados Unidos de América. Conclusiones. Nuestros resultados, sumados a otros resultados parecidos obtenidos en Brasil, Estados Unidos y Jamaica, indican que la infección por HVSK es poco frecuente en algunas poblaciones del hemisferio occidental y que está confinada mayormente a pacientes con KS en presencia de sida. 